Totanes, V. R. (2006). Money and leadership: A study of theses on public school libraries submitted to the University of the Philippines' Institute of Library and Information Science.

Presented at the Asia-Pacific Conference on Library \& Information Education \& Practice 2006 (A-LIEP 2006), Singapore, 3-6 April 2006, Nanyang Technological University.

\title{
Money and Leadership
}

A Study of Theses on Public School Libraries Submitted to the University of the Philippines' Institute of Library and Information Science

Vernon R. Totanes

Asia-Pacific Conference on Library \& Information

Education \& Practice

Nanyang Technological University

Wednesday, 5 April 2006

\section{Overview}

- No money for libraries

- Government should allocate budget

- After 65 years, time to accept the truth

- But why have some flourished?

- Other factors aside from money

- Case study of Quezon City libraries

- "Leadership" in one of 19 theses 


\section{The State of Philippine Public School Libraries}

- Almost 20\% of budget for education

- Reasons for problems

- Corruption

- 90\% for salaries (De Jesus)

- $6.5 \%$ for MOOE

- Funding from national and local governments (Belmonte)

- Quezon City's public schools lucky?

Books are merely accessioned.... The housing conditions provided for the library, if any, are poor.... The library is not open long enough for students to use it to the fullest extent.... The... librarians have not had any training in library work.

- Concordia Sanchez (1940) 


\section{Theses on Public School Libraries}

- 19 studies since 1940

- 13 Metro Manila, 5 provincial, 1 national

- 11 secondary, 8 elementary

- 17 relied mostly on questionnaires

- Standards by AASL (1960), BPS (1960), DECS (1988 and 1998)

- Public-private comparison

\section{Common Elements}

- Distributed questionnaires

- Compared facilities, books, equipment

- Studies say the same thing in different words (Sandiko)

- Did not meet standards or not on same level as private schools

- Reason: Lack of funds

- Findings, conclusion, recommendations: Libraries inadequate, government should allocate funds 


\section{Success Stories}

- Magazines and newspapers

- Only donor with money is required

- Between "before" and "after"?

- Can success be replicated?

- Is it really just about money?

\section{Beyond Money}

- "Leadership" appears in only one abstract

- Focus: Development of public secondary school libraries in Quezon City

- "There's no need to study the matter; you just need money." 


\section{Guidelines}

- Physical facilities

- Librarian and support staff

- Programs and services

- Collection

- Sources of funds

\section{Two Libraries}

- Levels of development quantified

- Two highest scorers compared

- SB e-Library project

- Similar budgets and populations

- One librarian vs three librarians 


\section{Juan Sumulong High School e-Library}

- Susan Torres

- Gets people to pay attention

- Started with thesis proposal

- Larger project drawn up

- Mayor became involved

- Project continues (money to burn?)

- Leadership before money

\section{Implications for LIS Education}

- More studies on public school libraries?

- Librarians must be proactive (e.g., action plans)

- Jobs not just about work, communication necessary (especially in developing countries)

- Leaders who can communicate vision

- Management classes not enough 


\section{Conclusion}

- Money is important

- Leaders needed to communicate and catch attention

- Two libraries with similar budgets will not necessarily achieve similar goals

- People, not money, put knowledge to work

\section{Money and Leadership}

A Study of Theses on Public School Libraries Submitted to the University of the Philippines' Institute of Library and Information Science

Vernon R. Totanes

Asia-Pacific Conference on Library \& Information

Education \& Practice

Nanyang Technological University

Wednesday, 5 April 2006 